\title{
Herbage production 47 years after severe wind erosion in the Hurunui River gorge
}

\author{
T.L. KNIGHT', D.C. WETHEY ${ }^{2}$ and B.E. ALLAN' ${ }^{1}$ \\ ${ }^{1}$ AgResearch, PO Box 60, Lincoln \\ *Canterbury Regional Council, PO Box 345, Christchurch
}

\begin{abstract}
Wind erosion can have severe long-term consequences on the soils of Canterbury. Pasture production was measured, in the 1992193 year, 47 years after a severe wind erosion event in the Hurunui gorge, North Canterbury. The topsoil was removed from this Tasman/Ashwick intergrade soil, exposing the underlying gravel. Herbage yields from the severely eroded site were very low and only $29 \%$ of those from an area which had retained $480 \mathrm{~mm}$ of topsoil. Both areas had been under the same management both before and since the erosion event. Where fertiliser had been applied to the area with retained topsoil, herbage yield was greater than where it had not been applied.
\end{abstract}

Keywords: erosion, herbage production, wind

Introduction

In July 1945 a severe wind erosion event affected an area of 1.08 ha in the upper Hurunui River gorge, approximately $20 \mathrm{~km}$ northwest of Hawarden. All of the topsoil of this Tasman/Ashwick intergrade soil was removed, exposing the gravel. Basher (1990) described the erosion event and estimated that $25 \mathrm{~cm}$ of topsoil or 3125 tha was lost and that this severely reduced the available fertility and more importantly reduced the available water holding capacity from $70-90 \mathrm{~mm}$ to $20-$ $25 \mathrm{~mm}$. Within the eroded area several small areas were left with varying amounts of the original topsoil intact.

The 1.08 ha area has had no improvements except for grazing and being used as a winter run-off, but the balance of the paddock has been topdressed. The ownership of the farm has remained with the same family and is now farmed by Mr J. Inch, who was able to confirm details of the management.

This site provided an opportunity to measure the effect of the erosion event and subsequent management on pasture production after 47 years.

\section{Experimental}

The eroded area is on a flat terrace above the Hurunui river gorge. Three areas for herbage measurement were identified within the paddock: (1) eroded/unimproved - on this area there was no remaining topsoil and no fertiliser had been applied; (2) topsoil/unimproved these areas were within the eroded area with no fertiliser but with $480 \mathrm{~mm}$ of retained topsoil; and (3) topsoily improved - this had a similar depth of retained topsoil as area 2 and $250 \mathrm{~kg} / \mathrm{ha}$ of superphosphate has been applied on three occasions over the last 8 years.

Seven small cages, $900 \times 600 \mathrm{~mm}$, were placed on each of the three areas and left in the same positions for the 12 months of measurement. The caged areas were trimmed to $10 \mathrm{~mm}$ height on 24 June 1992. An area of $500 \times 250 \mathrm{~mm}$ was cut inside each cage, to $10 \mathrm{~mm}$, when there was sufficient growth for a measurement. After the measurement area was cut the balance of the caged area was trimmed to the same height and all clippings were discarded.

Seven cuts were obtained. The material from each cage was weighed green, dried, weighed dry and retained for chemical analysis. On three occasions, spring, summer and winter, a sample of the green herbage was dissected into grass, legume, weed and dead material and the major species in each group identified. This was then dried and weighed.

At each cut the dried herbage from the cages within each of the three treatments was-bulked for total nitrogen analysis using the Kjeldahl digestion method.

Mean annual rainfali is $1000 \mathrm{~mm}$ and the area is affected by strong cold winds funnelling down the gorge. In 1992/93 the area received rainfall of $981 \mathrm{~mm}$ with cooler summer temperatures than average.

The data were analysed by the Minitab statistical package. For each variable two analyses were performed using independent sample $\boldsymbol{t}$ tests. Firstly the eroded and topsoil areas werecompared for the unimproved pasture. Secondly the unimproved, and improved (both topsoil) pastures were compared. Only one value per treatment was available for the total nitrogen variable, so this was analysed using a paired samples $\boldsymbol{t}$ test with cutting dates being treated as pairs.

\section{R e sult s}

In general topsoil/unimproved sites produced more than eroded/unimproved sites, and topsoil/improved produced more than the topsoil/unimproved (Table 1). 
Table 1 Herbage yield ( $\mathrm{kg} \mathrm{DM} / \mathrm{ha}$ ) for 1992/93, 47 years after severe wind erosion in the upper Hurunui river gorge.

\begin{tabular}{|c|c|c|c|c|c|c|c|c|}
\hline Treatment & $\begin{array}{c}16 \\
\text { September }\end{array}$ & $\begin{array}{c}16 \\
\text { October }\end{array}$ & $\begin{array}{c}23 \\
\text { November }\end{array}$ & $\begin{array}{c}16 \\
\text { December }\end{array}$ & $\begin{array}{c}16 \\
\text { February }\end{array}$ & $\begin{array}{c}29 \\
\text { March }\end{array}$ & $\begin{array}{c}24 \\
\text { June }\end{array}$ & $\begin{array}{c}1992 / \\
1993\end{array}$ \\
\hline Eroded/unimproved & $\begin{array}{c}162 \\
\cdots\end{array}$ & 25 & 91 & $\begin{array}{l}61 \\
\mathrm{~ns}\end{array}$ & 215 & 66 & 23 & 663 \\
\hline Topsoil/unimproved & 366 & 225 & 536 & $\begin{array}{r}137 \\
\mathrm{~ns}\end{array}$ & $\begin{array}{c}663 \\
\mathrm{~ns}\end{array}$ & $\mathrm{nSS}^{202}$ & 158 & 2307 \\
\hline Topsoil/improved & 1127 & 536 & 1334 & 141 & 440 & 407 & 270 & 4255 \\
\hline 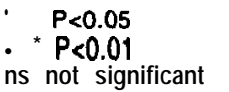 & & & & & & & & \\
\hline
\end{tabular}

In November and February (Table 2) the eroded/unimproved site had significantly less grass and more dead material compared with the topsoil/unimproved and in November the topsoil/unimproved site had less legume than the improved site. At the last cut in June the only significant difference between the eroded and topsoil treatments without fertiliser, was the higher weed percentage in the eroded plots. On the sites with retained topsoil the improved area had more legume and less weed and dead material than the unimproved.

The predominant grasses in all areas were red fescue (Festuca rubra) and browntop (Agrostis capillaris). The legumes in the eroded/unimproved area were suckling clover (Trifolium dubium) and haresfoot trefoil (Trifolium arvense) while the topsoil/unimproved areas included white clover (Trifolium repens) and the topsoil/improved site had predominately white and subterranean clover (Trifolium subterraneum). Hieracium pilosella was established on both the unimproved sites but there was little in the improved paddock area.

The eroded/unimproved vegetation had significantly lower levels of total nitrogen (Table 3) than the topsoil/unimproved vegetation but there was no significant difference between the two areas with retained topsoil.

\section{Discussion}

There has been very little natural improvement in the severely eroded/unimproved areas of the study site since the erosion event of July 1945. Pasture production from these areas was very low, and a considerable percentage of this was dead material and weed, mainly hieracium.
Table 2 Botanical composition of berbage produced in 1992/93, 47 years after severe wind erosion in the upper Hurunui river gorge.

\begin{tabular}{|c|c|c|c|c|c|}
\hline Date & Treatment & Grass & $\%$ Legume $\%$ & Weed \% & Dead \% \\
\hline \multirow[t]{5}{*}{$23 / 11 / 92$} & $\begin{array}{l}\text { Erodedl } \\
\text { unimproved }\end{array}$ & 14.3 & 20.3 & 22.3 & 43.1 \\
\hline & & ". & $\mathrm{ns}$ & ns & "n \\
\hline & $\begin{array}{l}\text { Topsoill } \\
\text { unimproved }\end{array}$ & 63.6 & 14.6 & 9.4 & 12.4 \\
\hline & & ns & . & ns & ns \\
\hline & $\begin{array}{l}\text { Topsoill } \\
\text { improved }\end{array}$ & 57.1 & 34.7 & 0.2 & 6.0 \\
\hline \multirow[t]{5}{*}{$16 / 2 / 93$} & $\begin{array}{l}\text { Erodedl } \\
\text { unimproved }\end{array}$ & 6.0 & 7.6 & 17.0 & 69.4 \\
\hline & & " & ns & ns & 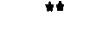 \\
\hline & $\begin{array}{l}\text { Topsoill } \\
\text { unimproved }\end{array}$ & 29.7 & 0.4 & 11.0 & 50.4 \\
\hline & & n s & $\mathrm{ns}$ & ns & $\mathrm{ns}$ \\
\hline & $\begin{array}{l}\text { Topsolly } \\
\text { improved }\end{array}$ & 36.8 & 6.6 & 0.6 & 54.0 \\
\hline \multirow[t]{5}{*}{$24 / 6 / 93$} & $\begin{array}{l}\text { Erodedl } \\
\text { unfmproved }\end{array}$ & 11.2 & 6.9 & 49.7 & 32.2 \\
\hline & & ns & $\mathrm{ns}$ & "* & ns \\
\hline & $\begin{array}{l}\text { Topsoill } \\
\text { unimproved }\end{array}$ & 21.4 & 23.0 & 11.6 & 43.8 \\
\hline & & ns & $\cdot$ & $\cdot$ & .. \\
\hline & $\begin{array}{l}\text { Topsoill } \\
\text { improved }\end{array}$ & 20.5 & 54.3 & 2.1 & 23.1 \\
\hline \multicolumn{6}{|c|}{$\begin{array}{l}\text { is } \quad P<0.05 \\
\text { ns not significant }\end{array}$} \\
\hline
\end{tabular}

Table 3 Total nitrogen levels (1992/93) in herbage produced 47 years after severe wind erosion in the upper Hurunui river gorge (mean of all cuts).

\begin{tabular}{lc}
\hline Treatment & Total nitrogen \% \\
\hline Eroded/unimproved & 1.72 \\
& \\
Topsoil/unimproved & 2.24 \\
Topsoil/improved & $n \mathrm{~s}$ \\
"t P<0.01 & 2.32 \\
ns not significant & \\
\hline
\end{tabular}


Areas with retained topsoil and no inputs of fertiliser produced over three times as much herbage as the eroded areas. and this herbage generally contained more grass and less dead material, with a significantly higher level of total nitrogen.

The paddock area with retained topsoil and fertiliser application produced $84 \%$ more herbage than the topsoil/ unimproved area and had a significantly higher proportion of legume at two of the three dissection dates. Although the levels of total nitrogen were similar, the improved area had more grass and legume and only low levels of hieracium infestation.

\section{ACKNOWLEDGEMENTS}

Mr. J. Inch for the use of the trial area, G. Hutchinson for pasture measurement and D.J. Saville for statistical analysis.

\section{REFERENCES}

Basher, L.R. 1990. Wind erosion and soil re-formation on a terrace in the upper Hurunui river gorge. DSL Technical Record CH6, Division of Land and Soil Sciences, Department of Scientific and Industrial Research. 